\title{
SELF-EMPLOYMENT IN NEW ZEALAND ${ }^{1}$
}

\author{
Richard Bururu
}

Department of Labour

This paper provides a preliminary analysis of self-employment in New Zealand. Using census data from Supermap 3 and HLFS data, we find that self-employment is growing with an increased proportion of the labour force being self-employed now than in 1986. This growth is however quite modest. Pull factors attracting people to self-employment appear to be stronger than push factors whereby people enter self-employment because of lack of alternative opportunities. However, results are not definitive. A possible causal relationship between self-employment and unemployment is explored using a time-series regression model. Results suggest a negative and significant relationship between self-employment and lagged unemployment rate. We also observe a weak but positive influence of the ECA, tax and intellectual property rights reforms on self-employment. There are regional differences in regard to factors that could be influencing individuals' decisions to enter into self-employment. While pull factors may explain entry into self-employment for Tasman, Marlborough Southland and West Coast regions, unemployment appears to be a strong factor for Northland, Taranaki, Waikato, and the Bay of Plenty. The analysis also looks at self-employment by occupation, qualifications, income, industry, age, gender and ethnicity. The paper concludes by mentioning policy implications and suggesting future research.

Key words: self-employment; push and pull factors.

New Zealand research on self-employment is quite limited $^{2}$ despite claims elsewhere that self-employment has grown considerably in the past decade, (see OECD, 1992 and Brownstein, 1996). This is in contrast to the OECD's commentary that academic research into the factors underlying the growth of self employment has blossomed (OECD, 1992 p155). This paper looks at the issue of self-employment in New Zealand and provides summary statistics. Our analysis is mainly descriptive and is meant to initiate further research in this area. The paper gives a labour market interpretation of the changes observed in the data. It is structured as follows; section 2 discusses the rationale for analysing self-employment; the push and pull factors of selfemployment are discussed in section 3 ; section 4 describes the characteristics of self-employed workers; in section 5 we summarise the results of a regression model and factors that affect self-employment growth; section 6 concludes the paper and suggestions for future research are offered in section 7 .

\section{Definition of self-employment and data sources}

Definition of self-employment varies considerably in different countries. Statistics New Zealand define self-employed individuals as those people who do not work for someone else and/or are not attached to any employer's premises. The definition includes those in paid work who employ others as well as themselves and those who work on their 'own account', employing no one else. Excluded from this definition are owner managers since they are employees of their own company under the income tax legislation. The definition conforms to that of the OECD. The OECD divide the self-employed into self-employed with employees ("employers"); self-employed without employees ("own-account workers"); members of producers' cooperatives and unpaid family workers. As observed by the ILO, it is sometimes difficult to decide whether one is selfemployed or not. Difficulties arise for individuals such as consultants and those who work for very short hours whose status lie between wage and salary work and self-employment (OECD, $1992 \mathrm{p} 156)$. The structure of the questions and how statisticians interpret responses determines the quality of the data ${ }^{3}$. Because of these problems, Hakim (1988) concludes that, "As a general rule, statistics of selfemployment are best used as a rough measure of change at the macro level".

\section{Data sources}

Data used comes from Statistics New Zealand; Census96 with Supermap3 and the Household Labour Force Survey (HLFS). Supermap3 is an electronic database that allows access to census information. It contains data from the 1986, 1991 and 1996 censuses - unit records are not retrievable. The HLFS that started in $\mathbf{1 9 8 5}$ is a quarterly survey of a sample of New Zealand households. Two questionnaires are interviewer administered and they collect demographic data on the household and on individuals' labour force 
Figure 1. Trend of self-employment workers from 1995 to 1997
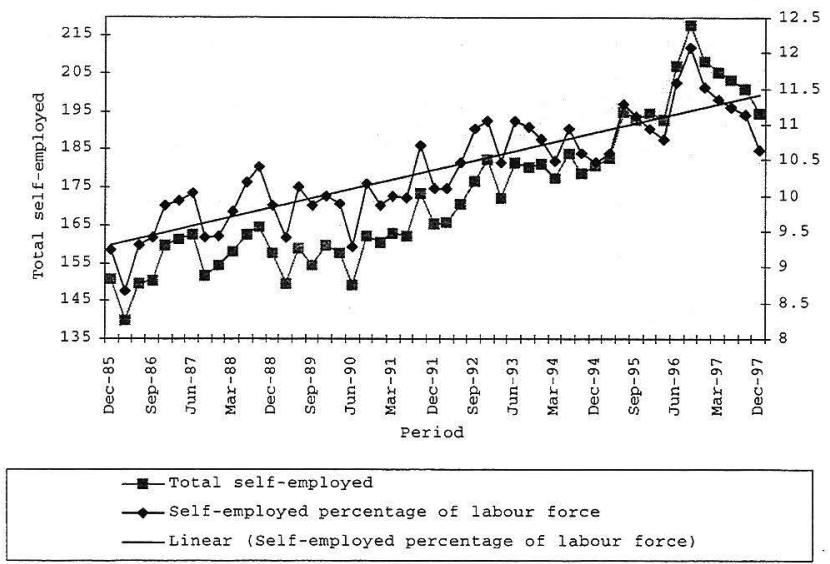

Source: Statistics New Zealand Census 96 with Supermap3

activity within the reference week immediately before the interview. Self-employed individuals fall under the employed category 4 . The time series HLFS data is broken down by age group, industry, occupation (since 1990), hours usually worked, ethnic group and qualifications. These smaller aggregates however suffer from large sampling errors.

\section{A modest growth of self-employment observed in the 1990 's}

The number of self-employed workers has had a modest but sustained growth over the past ten years. Census data shows that full-time self-employed increased from 226,320 to 250,635 and part-timers increased by 26,346 to 57,039 . Figure 1 shows an upward trend of self-employment from 1985 to 1997 . Data from the Household Labour Force Survey (HLFS) show that the absolute number of the self-employed workers increased by 19.9 percent between the December 1985 quarter and the December 1997 quarter. As a percentage of the labour force, the number of selfemployed has increased from 9.4 percent to 10.6 percent. This shows 1.5 percentage points down from the September 1996 quarter peak of 12.1 percent. As the percentage of the labour force, the 1996 figure is just showing a recovery from a considerable decline between 1986 and 1991. Unlike full-time self-employment, part-timers have shown growth both in absolute and relative terms. The growth pattern of self-employment and non standard work is similar to that observed overseas (see OECD, 1992; Lee, 1996; Kirchhof, 1996; Brownstein, 1996)

\section{Rationale for analysing self-employment}

Although self-employment has always been a feature of the New Zealand economy ${ }^{5}$, it has not received much policy attention. Understanding the growth patterns and characteristics of individuals who are self-employed will enhance development of policies that affect this sector. Since selfemployed enterprises tend to be small, labour intensive, high risk, and with less stable income, growth in self-employment could raise new challenges in areas such as:

- Tax and ACC administration - an influx of self-employed individuals implies a large dispersion of where taxes or ACC levies are collected which raises the cost of the taxes and levies on the economy ${ }^{6}$. Also, problems of tax avoidance and evasion tend to rise with self-employment. Franz (1985) concludes that tax evasion by the self-employed might be 1.5 percent of total Austrian tax revenue. Casey (1991) makes a similar conclusion in the case of the United Kingdom.

- Social welfare - initially those in self-employment tend to be insecure and poorly paid which may mean a continued reliance on benefits.

- Occupation, health and safety - it is more difficult and costly to monitor health and safety in numerous small business operations. New Zealand research suggests that small firms could be experiencing occupational health and safety problems (Mears and Sundakov, 1998; Bururu, 1998). 
Recognition of the extent of self-employment also improves general labour market statistics such as unemployment, employment and labour market participation. And having accurate labour market statistics is crucial for labour market policy development.

\section{The 'push' and 'pull' factors of self- employment}

Growth in self-employment can be explained in terms of push and pull factors. Pull factors are indicative of the attractiveness of self-employment ventures while push factors relate to weak labour markets resulting in poor employment alternatives. The OECD (1992) after Rasse and Parisot (1989) summarise the pull and push factors as:

"If the prospects for business are better, people may be drawn [pulled] into self-employment by its intrinsic attraction, though entry might be precipitated [pushed] by a crisis such as a spell of unemployment".

Push and pull factors' overall effect on self-employment depends on the industrial relations system and regulatory framework in which the labour market operates. For example, highly regulated labour markets that make it difficult to hire and fire workers may encourage employers to contract out services to minimise labour transaction costs? Increasing non-wage labour cost such as ACC levies, payroll taxes and health and safety compliance costs may also lead to a high level of contracting arrangements. At the same time, rigid working arrangements may force individuals who prefer work flexibility to opt out of wage and salary employment. Overall, self-employment can be seen as having an enabling effect on labour market flexibility. Instead of firms getting into a contract of employment that is more rigid, they enter into a more flexible contract of services. Beatson (1995), after observing the United Kingdom data, comments that "growth in self-employment in the 1980s may have been conducive to greater market flexibility". Table 1 gives a summary of the push and pull factors.

\section{Characteristics of the self-employed}

This section looks at self-employed workers' characteristics. The section addresses three interrelated questions: 1) Who is self-employed? - in terms of qualifications, occupation, ethnicity, age and gender; 2) How do they compare to wage and salary workers in terms of income, hours and industry distribution? 3) What is the relationship between these characteristics? Unless stated otherwise, the proportions refer to total employment (self-employment plus wage and salary workers) both part-time and full-time.

\section{Overview}

Overall, Asians followed by those of European origin are most likely to be in self-employment. Pacific Islanders are least likely to be in self-employment. The agricultural industry still dominates as the employer of self-employed workers. Qualification levels of the self-employed are similar to those of employees; with most of both groups having no qualifications. Tasman region has the highest rate of selfemployment whilst Wellington is at the bottom. The selfemployed are over-represented in the extremes of the income distribution spectrum (they also reported long working hours). Most of the self-employed workers tend be older and this pattern is similar for both sexes.

\section{Self-employment by gender and age}

As shown in Table 2, self-employment is more common among men than women. The census figures show that in $1996,57,780$ females and 192,855 males were self-employed. The number of self-employed women has increased steadily since 1986 . In contrast, the number of men selfemployed has had a slight drop since 1991. Self-employment time-series by gender indicates that the drop observed in total self-employment was due to a decline in the proportion of men who are self-employed ${ }^{\star}$. Workers in the 35 65 age range are more likely to be self-employed than workers in other age groups.

\section{Table 1. Push and pull factors}

\section{Pull factors}

Easy access to capital

High returns to self-employment

Increased proportion of small firms in the economy

Flexibility to both firms and employees

Low corporate tax rate

Being your own boss

Less rigid contracts for services

\section{Push factors}

Rising unemployment

Rigid wage/salary working conditions

Demographic composition - high proportion ofyoung children and women in the labour force*

Non transferable skills

High marginal rate of personaltaxation

Location and high relocation costs

More rigid contracts of employment

* Appendix 1 shows the changes in the age work profile of women. It shows that women's participation has increased dramatically in the past two decades. 
Table 2. Self-employment by gender and age

\begin{tabular}{|c|c|c|c|c|}
\hline \multirow[b]{2}{*}{ Age } & \multicolumn{2}{|c|}{ Wage and Salary } & \multicolumn{2}{|c|}{ Self-employed } \\
\hline & Male & Female & Male & Female \\
\hline \multirow[t]{3}{*}{$15-24$} & 103611 & 80451 & 4509 & 1665 \\
\hline & 54.5 (row percent) $^{1}$ & 42.3 & 2.4 & 0.9 \\
\hline & 18.8 (column percent $)^{2}$ & 20.8 & 2.3 & 2.9 \\
\hline \multirow[t]{3}{*}{$25-34$} & 163479 & 108402 & 34374 & 10479 \\
\hline & 51.6 & 34.2 & 10.9 & 3.3 \\
\hline & 29.6 & 28.0 & 17.8 & 18.1 \\
\hline \multirow[t]{3}{*}{$35-44$} & 137094 & 92325 & 61209 & 19050 \\
\hline & 44.3 & 29.8 & 19.8 & 6.2 \\
\hline & 24.8 & 23.8 & 31.7 & 33.0 \\
\hline \multirow[t]{3}{*}{$45-54$} & 101139 & 80553 & 57309 & 18486 \\
\hline & 39.3 & 31.3 & 22.3 & 7.2 \\
\hline & 18.3 & 20.8 & 29.7 & 32.0 \\
\hline \multirow[t]{3}{*}{$55-64$} & 43482 & 24669 & 28722 & 6996 \\
\hline & 41.9 & 23.8 & 27.7 & 6.7 \\
\hline & 7.9 & 6.4 & 14.9 & 12.1 \\
\hline \multirow[t]{3}{*}{$65+$} & 2916 & 1047 & 6732 & 1104 \\
\hline & 24.7 & 8.9 & 57.1 & 9.4 \\
\hline & 0.5 & 0.3 & 3.5 & 1.9 \\
\hline
\end{tabular}

Note: 1 - the row percentage, that is 54.5 percent of $15-24$ year old males earn a wage or salary

2 - the column percentage, that is 18.8 percent of male wage and salary earners are within the $15-24$ year group

Distribution of self-employment by occupation and qualification

Figures 2 and 3 show the distribution of self-employed workers by occupation and qualification respectively. A majority of the self-employed is in trades occupations such as building and in traditional occupations such as agriculture and fishery. About 35 percent of those in corporate management are self-employed. Recent increases in contracting opportunities may explain the relatively high proportion of self-employed workers in the associate professional category. It is noteworthy that the proportion of selfemployed and wage and salary workers is well matched across the different qualifications. The self-employed are still over-represented at the lower end of the qualifications' scale. Qualified self-employed individuals tend to have skills vocational training.

Lack of formal qualifications could be pushing some workers into self-employment, or individuals with particular trade skills may find it more attractive to be self-employed". Returns for low qualifications might also be higher in selfemployment than in wage and salary work, or it may have become more difficult for individuals with low qualifications to get wage and salary work.

\section{Self-employment by ethnicity}

Table 3 shows that 90 percent and 87.2 percent of self- employed males and females respectively are of European origin. A large proportion of Asian females are self-employed compared to women in any other ethnic group. Figures show that Pacific Islanders followed by Maori are least likely to be self-employed. Asians are the most likely to be self-employed with the data showing a considerable jump in this group between 1991 and 1996 (see figure 4). Bates (1997) explains this pattern in terms of language barriers to employment, and cultural factors. This implies that Asians might be facing stronger push factors than other ethnic groups.

\section{High concentration of self-employed in the agricul. ture industry}

Many self-employed workers are in the agriculture industry, with relatively high proportions also in construction, retail trade and property and business services (see Table 4). These industries are characterised by the dominance of family farms and small businesses. Also, restructuring of the Forestry sector saw a massive growth of small 'oneman' ventures. The low amount of initial capital required to start up these ventures may partly explain this pattern For instance, the low rate of self-employment in mining, utilities and public goods supply indicate the dominance of central government as major provider (in the case of government administration, defence and education) or high initial capital outlays required (in the case of mining). ${ }^{10}$ 
Figure 2. Distribution of self-employed workers by occupation, 1996

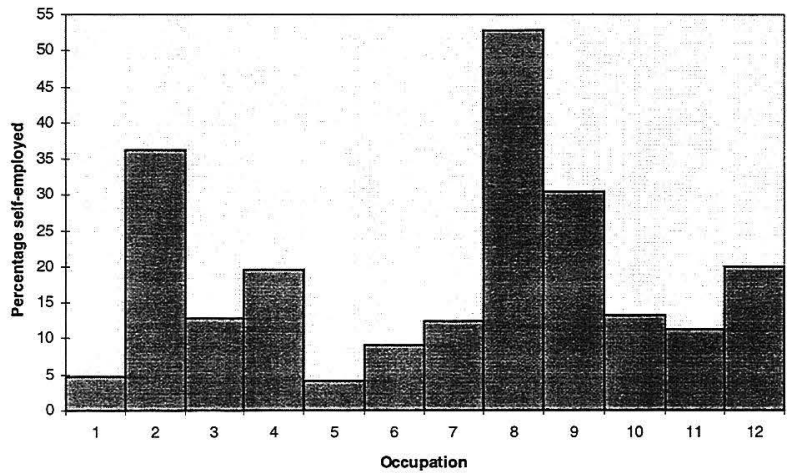

1. Legislators and Administrators; 2. Corporate managers; 3. Professionals; 4. Associate professionals; 5. Clerk; 6. Personal and Protective Services Workers; 7. Salespersons, Demonstrators and Models; 8. Market Oriented Agricultural and Fishery workers; 9. Trades Workers; 10. Machine and plant operators; 11. Building and labourers; 12. Not Specified.

Source: Statistics New Zealand Census 96 with Supermap3

Figure 3. Highest qualification attained by wage/salary and self-employed workers, 1996

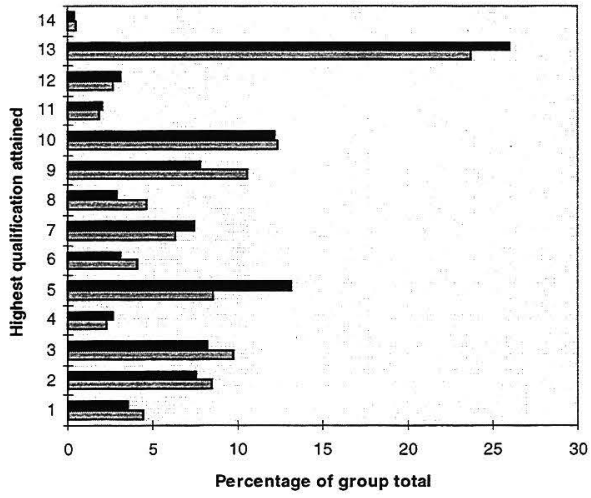

日 Proportion of Wage and Salary

Proportion of Self employed

1. Higher degree; 2. Bachelor degree; 3. Advanced vocational qualification; 4. Intermediate vocation qualification; 5. Skilled vocational qualification; 6. Basic vocational qualification; 7. Post school qualification not specified; 8. Higher school qualification; 9. Sixth form qualification; 10. School Certificate qualification; 11. Overseas school qualification; 12. School qualification not specified; 13 . No qualification; 14 . Not specified. 


\section{Regional variation}

The percentage of the labour force engaged in self-employment varies from a high of 17.5 percent for the Tasman region to a low of 10.7 percent for the Wellington region (see Figure 5). There is little variation across the regions in terms of gender. Gisborne and Hawkes Bay regions have the lowest number of females in self-employment - 20.6 percent and 21.3 percent respectively. Taranaki has the highest percentage with 26.6 percent in self-employment. These figures do not match the observed variation of population split by gender where Wellington has the highest percentage of females in the labour force and Southland has the lowest.

In trying to understand the influence of the effects of pull and push factors, we analysed the relationship between regional unemployment rate and self-employment. Figure 6 shows this relationship. The negative part of the unemployment axis shows regions with an unemployment rate below the national average. The positive part of the axis shows those above the average. On the self-employment axis, the positive part shows regions with a self-employment rate above the national average, and the negative axis shows regions below the national average.

Regions in the positive quadrant have high rates of both unemployment and self-employment. This suggests that individuals in these regions are being pushed into self-employment. On the other hand, individuals in regions within the North West quadrant (Tasman Marlborough, Southland and the West Coast) might be experiencing pull factors. Gisborne, Manawatu-Wanganui and the Hawke's Bay regions, although having high rates of unemployment, still have low rates of self-employment. Coincidentally these regions also tend to have a large percentage of people on social welfare benefits. For example, Gisborne has the highest percentage of working age people on benefits whilst Manawatu-Wangnui and the Hawke's Bay feature in the top eight. Regions with relatively high formal employment growth rates like Auckland, Nelson, Wellington, Canterbury and Otago appear to have relatively low rates of selfemployment. This may suggest that individuals are more inclined to go into wage and salary work rather than selfemployment.

\section{Earnings of self-employed workers}

Just over 15.0 percent of the self-employed earn $\$ 30001$ to $\$ 40000$ which coincides with the modal income band for the wage and salary workers (see Table 5). There is however a disproportionate representation of the self-employed in extremes of the income spectrum. Relatively high earnings of the self-employed may be due to the number of hours worked and age distribution. New Zealand data shows that the self-employed work for longer hours than wage and salary employees. While this data may be biased somewhat by self-employed reporting longer hours than they actually work, evidence from other OECD countries also shows self-employed people working for long hours. There is some anecdotal evidence that suggests that self-employed individuals tend to under-report their income.

\section{Hours of work}

Table 6 shows the distribution of hours worked by fulltime wage/salary and self-employed workers. It shows that relatively more self-employed workers work for longer hours although the peak is at $40-49$ hours, which is the same for salary/wage workers. For example in 1996, 30.6 percent of the self-employed workers compared to only 7.9 percent of the wage/salary full-time workers worked for

Table 3. Ethnicity and self-employment

\begin{tabular}{|c|c|c|c|c|}
\hline & Wage and & & Self-em & \\
\hline Ethnicity & Male & Female & Male & Female \\
\hline European & $\begin{array}{ll}439128 & \\
45.3 & \text { (row percent) } \\
80.1 & \text { (columnpercent) }\end{array}$ & $\begin{array}{l}308283 \\
31.8 \\
80.1\end{array}$ & $\begin{array}{l}172335 \\
17.8 \\
90.0\end{array}$ & $\begin{array}{l}50049 \\
5.2 \\
87.2\end{array}$ \\
\hline NZ Maori & $\begin{array}{l}67461 \\
53.5 \\
12 . .3 \\
\end{array}$ & $\begin{array}{l}45249 \\
35.9 \\
11.8\end{array}$ & $\begin{array}{l}10104 \\
8.0 \\
5.3\end{array}$ & $\begin{array}{l}3183 \\
2.5 \\
5.5 \\
\end{array}$ \\
\hline Pacific Island & $\begin{array}{l}23448 \\
53.8 \\
4.3 \\
\end{array}$ & $\begin{array}{l}17394 \\
39.9 \\
4.5 \\
\end{array}$ & $\begin{array}{l}2037 \\
4.7 \\
1.1 \\
\end{array}$ & $\begin{array}{l}678 \\
1.6 \\
1.2\end{array}$ \\
\hline Asian & $\begin{array}{l}16041 \\
41.2 \\
2.9\end{array}$ & $\begin{array}{l}13074 \\
33.6 \\
3.4\end{array}$ & $\begin{array}{l}6480 \\
16.6 \\
3.4\end{array}$ & $\begin{array}{l}3339 \\
8.6 \\
5.8\end{array}$ \\
\hline Other & $\begin{array}{l}1830 \\
52.8 \\
0.3\end{array}$ & $\begin{array}{l}921 \\
26.6 \\
0.2\end{array}$ & $\begin{array}{l}540 \\
15.6 \\
0.3\end{array}$ & $\begin{array}{l}177 \\
5.1 \\
0.3\end{array}$ \\
\hline
\end{tabular}

Note: 1 - the row percentage, that is 45.3 percent of European males earn a wage or salary.

2 - is the column percentage, that is 80.1 percent of male wage and salary earners are of European origin. 


\begin{tabular}{|lccc|}
\hline Industry & Wage and salary & Self-employed & $\begin{array}{c}\text { Percentage } \\
\text { self-employed }\end{array}$ \\
Agriculture, Forestry and Fishing & 51375 & 50280 & 49 \\
Mining & 3420 & 291 & 8 \\
Manufacturing & 179871 & 23151 & 11 \\
Electricity, Gas and Water Supply & 8118 & 219 & 3 \\
Construction & 48744 & 32454 & 40 \\
Wholesale trade & 68985 & 11301 & 14 \\
Retail trade & 92115 & 36147 & 28 \\
Accommodation, Cafes and Restaurants & 30843 & 8562 & 22 \\
Transport and storage & 43611 & 9045 & 17 \\
Communication Services & 15783 & 2643 & 14 \\
Finance and insurance & 40011 & 3711 & 8 \\
Property and business services & 92565 & 34596 & 27 \\
Government administration and defence & 57966 & 0 & 0 \\
Education & 71472 & 1533 & 10 \\
Health and community services & 62010 & 7221 & 21 \\
Cultural and recreational services & 17631 & 4740 & 21 \\
Personal and other services & 33540 & 8697 & \\
\hline
\end{tabular}

more than 60 hours a week. This pattern could also be due to reporting bias in the hours data. It is worthwhile to calculate and compare the income per hour worked for the two groups. ${ }^{.1}$

\section{Are self-employed employing others?}

In 1996 about 81.0 percent of the self-employed had employees showing a decline from the 1986 level of 88.0 percent (see Figure 7). These figures lend support to programmes that promote self-employment as a vehicle for job creation. In the short run, the impact of self-employment on unemployment depends on both the numbers of jobs created by the self-employed, the nature of jobs (degree of specialisation) and the propensity of self-employed workers to employ the unemployed rather than other wage and salary workers. In the long run, sustained self-employment growth could have a positive employment effect as vacancies created by wage and salary workers open opportunities for unemployed workers ${ }^{12}$. However we need to be cautious about the effects of self-employment on unemployment. As observed by the OECD (1992), not all selfemployment is job creation; some forms of subcontracting to the self-employed can be regarded as displacement from wage and salary employment. The OECD survey notes that self employment can contribute to the mobilisation of labour supply by helping people maintain contact with the labour market as they pass from one labour market state to another.

\section{Possible labour market factors affecting self- employment.}

The main question that arises from this analysis is: What has caused this moderate rise in self employment? In sec- tion 3 we discussed the pull and push factors of self-employment and noted that pull and push factors are not mutually exclusive. In this section we discuss some of the changes in the new Zealand economy, particularly the labour market, that may have resulted in prominence of some of the push and pull factors. Firstly, the labour market reforms and a decline of labour union activity facilitated creation of more flexible employment relationships and may have opened opportunities for self-employment ${ }^{13}$. Secondly, the product market reforms together with downsizing of large companies may also have resulted in a more competitive environment that is conducive for starting own businesses. Thirdly, other factors including easy access to capital (resulting from financial market reforms), recognition of intellectual property rights and franchising may have also attracted people into self-employment. Fourthly, changes to ACC legislation and introduction of experience rating could have resulted in firms contracting out their more risky activities.

Table 7 shows results from a time series regression model. The results suggest that: 1) there was growth in self-employment after the passing of the Employer Contracts Act (ECA); 2) the lagged unemployment rate had a negative impact on entry into self-employment; and 3) disappearing wage and salary jobs in the previous period increased the rate of self-employment. Personal tax and intellectual property reforms, though statistically insignificant, had a positive influence on self-employment. These results are partially consistent with labour market flexibility story. It also suggests that pull factors could be dominant thereby attracting people into self-employment. A negative and statistically significant coefficient on the lagged unemployment variable and a significant positive coefficient on the 


\section{Figure 4. Self-employment by ethnicity}

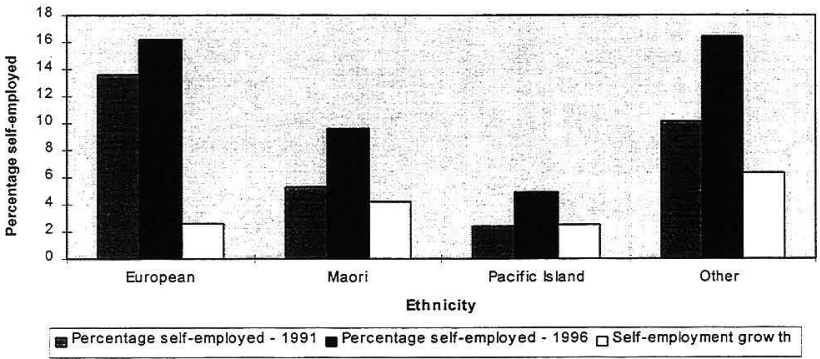

Source: Statistics New Zealand Census 96 with Supermap3

ECA dummy variable support this conclusion. However, the negative relationship between wage and salary jobs in the previous period and self-employment suggest that people are more inclined to get into wage and salary employment rather than self-employment.

Overall, the results suggest that individuals are getting into self-employment in anticipation of better business prospects and higher returns rather than pushed by a crisis such as a spell of unemployment. However, the results also suggest that it is important to consider regional and ethnic differences. We conclude this section by suggesting that a better understanding of the pull and push factors requires direct interviews of people in self-employment. A lot of information can be obtained by asking why the self-employed people chose self-employment as an employment option. Such an approach needs to be weighed against the high cost of interviews.

\section{Conclusion and policy implications}

The number of self-employed has had a modest but sustained growth over the past ten years. Full-time self-employed increased from 226,320 to 250,635 and part-timers increased by 26,346 to 57,039 . Most self-employed workers are European but those of Asian origin have shown

\section{Figure 5. Self-employment by region}

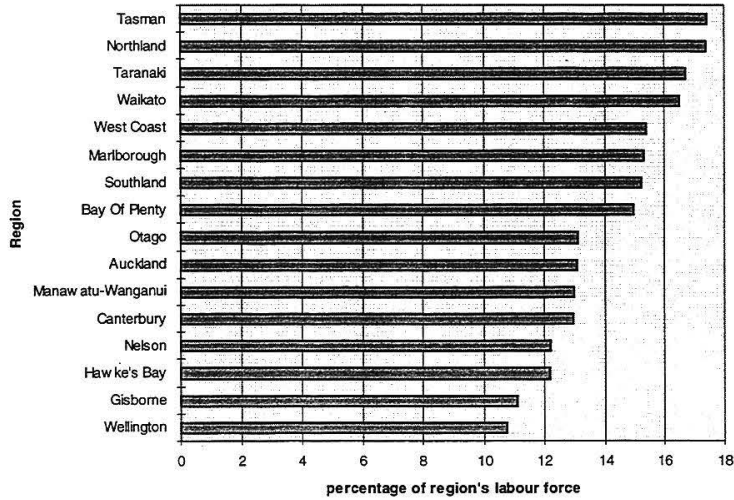

Source: Statistics New Zealand Census 96 with Supermap3 
strong growth. Pacific Islanders followed by Maori are the least likely to be in self-employment. The agricultural industry still dominates as the employer of self-employed workers. Qualifications distributions of self-employed and wage and salary workers are similar; with most of the people not having any qualifications. The self-employed are over-represented in the extremes of the income distribution spectrum (they also work for longer hours). Most of the self-employed workers tend be older and this pattern is similar for both sexes.
It will be interesting to know whether self-employment has had an impact on the unemployment rate. We could not get a conclusive answer to this question at this stage. However, we would expect the observed growth of self-employed workers to have a long run positive effect on unemployment. Self-employment can also complement other current employment programmes particularly those that fail to match supply to the demand of labour ${ }^{15}$. Self-employment has an enabling effect on labour market flexibility. Instead of firms entering a rigid contract of employment,

Table 5. Income distribution of wage/salary and self-employed workers

\begin{tabular}{|llllll|}
\hline Employment Status & Wage/salary & Self-employed & $\begin{array}{c}\text { Percentage } \\
\text { self- } \\
\text { employed }\end{array}$ & $\begin{array}{l}\text { Proportion of Proportion of } \\
\text { self- } \\
\text { employed }\end{array}$ & wage/salary \\
Loss & 495 & 5514 & 91.8 & 2.3 & 0.1 \\
Zero Income & 18 & 1431 & 98.8 & 0.6 & 0.002 \\
$1-5000$ & 25794 & 5334 & 17.1 & 2.2 & 2.8 \\
$5001-10000$ & 40623 & 12933 & 24.1 & 5.3 & 4.4 \\
$10001-15000$ & 65649 & 20670 & 23.9 & 8.5 & 7.2 \\
$15001-20000$ & 96420 & 23574 & 19.6 & 9.7 & 10.6 \\
$20001-25000$ & 130962 & 24267 & 15.6 & 10.0 & 14.3 \\
$25001-30000$ & 148719 & 29049 & 16.3 & 12.0 & 16.3 \\
$30001-40000$ & 198441 & 38238 & 16.2 & 15.8 & 21.7 \\
$40001-50000$ & 103539 & 22902 & 18.1 & 9.5 & 11.3 \\
$50001-70000$ & 66492 & 23202 & 25.9 & 9.6 & 7.3 \\
$70001-100000$ & 23493 & 15012 & 39.0 & 6.2 & 2.6 \\
$100000+$ & 13221 & 20193 & 60.4 & 8.3 & 1.5 \\
Source: Statistics New Zealand Census 96 with Supermap3 & & & \\
\hline
\end{tabular}

Figure 6. Self-employment and unemployment rate by region

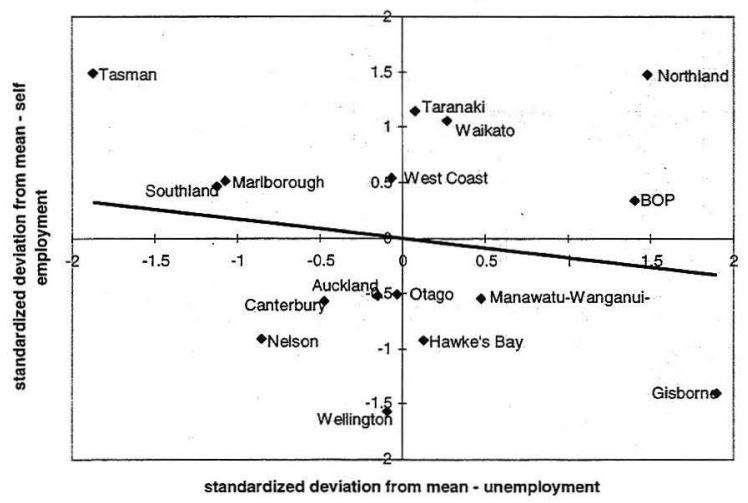

Source: Statistics New Zealand Census 96 with Supermap3 
Table 6. Distribution of hours worked

\begin{tabular}{|l|l|l|l|l|l|}
\hline $\begin{array}{l}\text { Hours worked per } \\
\text { week }\end{array}$ & $\begin{array}{l}\text { Wage and } \\
\text { salary }\end{array}$ & Self-employed & $\begin{array}{l}\text { Percentage } \\
\text { self-employed }\end{array}$ & $\begin{array}{l}\text { Proportion of } \\
\text { self-employed }\end{array}$ & $\begin{array}{l}\text { Proportion of } \\
\text { wage/salary }\end{array}$ \\
\hline $1-9$ & 927 & 387 & 29.5 & 0.2 & 0.1 \\
\hline $10-19$ & 4221 & 1329 & 23.9 & 0.6 & 0.5 \\
\hline $20-29$ & 12213 & 3915 & 24.3 & 1.6 & 1.3 \\
\hline $30-39$ & 144126 & 27006 & 15.8 & 11.2 & 15.7 \\
\hline $40-49$ & 553368 & 76446 & 12.1 & 31.7 & 60.4 \\
\hline $50-59$ & 129177 & 58035 & 31.0 & 24.1 & 14.1 \\
\hline $60-69$ & 51096 & 44313 & 46.4 & 18.4 & 5.6 \\
\hline $70+$ & 20835 & 29346 & 58.5 & 12.2 & 2.3 \\
\hline
\end{tabular}

Source: Statistics New Zealand Census 96 with Supermap3

they have the option of contracting services that are more flexible. To individuals, self-employment offers flexibility of work hours and working arrangements. To this end, selfemployment should be considered as an option when formulating the government's employment strategy. The OECD (1992) concludes that, "self employment growth may be stimulated by supportive government policies, including schemes to help the unemployed set up in business, efforts to reduce barriers to entry, and helping in securing the financial resources and skills necessary for success. In this way the governments can help develop the entrepreneurial base of their economies".

\section{Future research}

The paper has shown that self-employment has had a modest but sustained growth and may become an important part of the labour market. It is worth extending this analysis into framework that can provide an insight into the dynamics of the self-employed. We would like to know the fac- tors that influence self-employment entry and exit rates. Application of transition probabilities ${ }^{14}$ based on the HLFS may shed light to this question (see also Grimmond, 1993). Alternatively we can use duration analysis and, based on the survival functions, draw conclusions on factors that influence the survival rate of self-employed individuals.

Other issues related to growth in self-employment raised in overseas studies that prompt closer attention include:

- unstable incomes of self-employed workers and associated economic volatility;

- effect of self-employment on discouraged workers;

- demand side effect of self-employment on a subdued labour market;

- welfare and income distribution effects of self-employment; and

- labour market flexibility.

Figure 7. Proportion of self-employed workers employing others

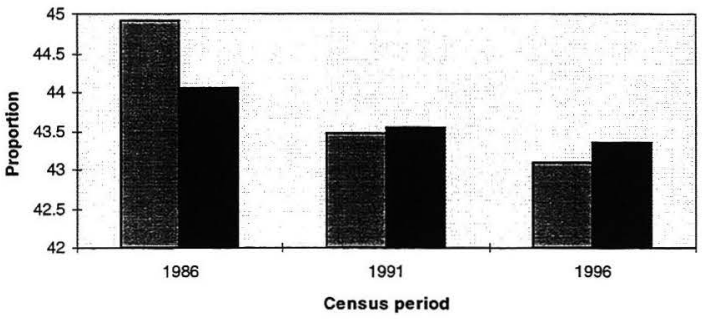

国 With employees Male $\quad$ With employees Female 
Table 7. Self employment regression results

\begin{tabular}{|l|r|r|}
\hline Variable & Coefficient & t-value \\
\hline Constant & 7.8359 & $2.31^{* *}$ \\
\hline Log of Unemployment rate lagged one period & -0.28884 & $-3.493^{*}$ \\
\hline Log of real wages & 0.13849 & 0.202 \\
\hline Log of real wages lagged one period & 0.21249 & 0.363 \\
\hline Log of wage/salary employment rate & -0.12777 & -0.214 \\
\hline Log of wage/salary employment rate lagged one period & -1.3547 & $-1.672 * * *$ \\
\hline Log of the business cycle proxy (NZIER QSBO) & 0.014911 & 1.217 \\
\hline ECA dummy variable = 1post ECA; 0 otherwise & 0.052195 & 1.868 \\
\hline Personal tax reforms dummy = 1 after reforms; 0 otherwise & 0.021264 & 0.645 \\
\hline $\begin{array}{l}\text { Removal of state regulated monopoly rights dummy = 1 after reforms; 0 } \\
\text { otherwise }\end{array}$ & -0.02845 & -1.045 \\
\hline $\begin{array}{l}\text { Review of intellectual property regime (patents, trademarks, copyright and } \\
\text { designs = 1 after review; 0 otherwise }\end{array}$ & 0.000158 & 0.006 \\
\hline $\begin{array}{l}\mathbf{R}^{2}=0.817003 ; \text { Durbin Watson }=1.92 \\
* \text { significant at 1 percent; ** significant at 5 percent; *** significant at 10 percent }\end{array}$ & \\
\hline
\end{tabular}

\section{Notes}

1 Paper presented at the Labour, Employment and Work Conference, Wellington 26-27 November 1998. The research was supported by the Labour Market Policy Group. Opinions and conclusions expressed in this paper are those of the author and do not necessarily reflect the opinions or policy of the Labour Market Policy Group. I thank Bernard Hodgetts, Bryan Chapple, Dave Maré, David Irwin, Duncan Melville, Maria Gobbi and Simon Chapple for providing helpful comments. Any remaining errors are my own and comments are welcome (see auther address at end of paper).

2 Whatman (1994) reviewed aspects of non standard work in New Zealand. The National Advisory Council on the Employment of Women (1993) provided detailed analysis of women who are self-employed. The other research on small businesses and self-employment is now dated (see Dwyer et al, 1985)

3 Depending on the information available, New Zealand (similar to Australia, Canada, France, Japan, The Netherlands, Norway and the United States) asks for information on the legal status of those who report themselves as self-employed and then class them on that basis in their self-employment series (OECD, 1992).

4 The employed category is defined as anyone who worked for one hour or more for pay or profit; worked without pay for one hour or more in work which contributed directly to the operation of a business owned or operated by a relative; or had a job but were not at work due to extenuating factor such as illness, leave or industrial dispute.

5 A large proportion of the firms are small and historically, the family farm-firm has played an important role in the New Zealand economy.
6 The current accident compensation scheme has problems dealing with the self-employed. Earnings data is sometimes difficult to get delaying compensation payments. Since compensation payments are based on the most recent earnings before an injury, compensation payments do not always reflect premiums paid which may act as a disincentive towards injury prevention.

7 A highly regulated market can also impinge on selfemployment growth. There can be a simultaneous effect between labour market flexibility and self-employment growth.

8 Everything being equal many women with children would prefer the more flexible work arrangements that are offered by self-employment.

9 Ideally, we would like to test if these differences are significant.

10 Compliance problems with the Resource Management Act could also explain low self-employment rates in mining.

11 Unit record data on income is generally not available one can use Statistics New Zealand Data Laboratory for more detailed research.

12 As observed elsewhere, programmes that encourage self-employment need to consider: dead-weight losses; displacement; the rationale for self-employment; and the target groups for self-employment.

13 The increased tendency of contracting out services such as tax and financial advice and project management has also provided a wider scope for self-employment. Some anecdotal evidence suggest that using self-employed 
contractors reduces overhead costs of employers. The decline of unions may have opened opportunities of selfemployment in areas that were once reserved for union members.

14 Transition probabilities measure the likelihood that a person who is self-employed in one quarter will be selfemployed (or in other employment/unemployed/not in the labor force) one quarter later.

15 Education and training programmes tend to have a high failure rate of matching labour supply to demand.

\section{References}

Bates, T. (1997) Race, Self-employment, and Upward Mobility: An Illusive American Dream. New York: John Hopkins University Press

Beatson, M. (1995) Labour Market Flexibility, Employment Department, Employment Market Research Unit: London

Blau, D. (1987) A time series analysis of self-employment in the United States, Journal of Political Economy, 95(3): 445-467

Borjas, G. and Bronars, S.G. (1988) Consumer discrimination and self employment, NBER Working $\mathrm{Pa}$ per No. 2627

Brownstein, R. (1996) Self-employed emerge as a new political force, The Detroit News, May 5

Bururu, R. (1998) Economic and labour market effects on accident compensation claim rates, Unpublished report, Department of Labour: Wellington.

Casey, B. (1991) Self-employment in Britain, 1979-90, OECD Secretariat, UK Policy studies Institute: London
CEG (1997) Be your own boss: National outcomes report 1995-1996, Department of Labour: Wellington.

Curtin, M. (1996) A review of enterprise allowance and the capitalisation option, NZES, Department of Labour: Wellington.

Dennard, H. L. (1996) Government impediments to the employment of contingent workers, Journal of Labour Research, XVII(4) Fall: 595-612

Dunn, P. and Holtz-Eakin, D. (1996) Financial capital, human capital and the transition to self- employment: evidence from intergenerational links, NBER Working Paper No. 5622

Dwyer, M., Rose, D. and Sowman, R. (1985) Self-employment and small business, New Zealand Planning Council: Wellington

Franz, A. (1985) Estimates of the hidden economy in Austria on the basic official statistics, Review of Income and Wealth, Vol 31, No.4, December., 325 336.

Hakim, C. (1988) Self-employment in Britain: Recent trends and current issues, Work, Employment and Society, 2(4): 421-450

Kirchoff, B. A. (1996) Self-employment and Dynamic Capitalism, Journal of Labour Research, XVII(4) Fall: $627-644$

Lee, D. R. (1996) Why is flexible employment increasing?, Journal of Labour Research, XVII(4), Fall: 543-554.

Mears T. and Sunidakov A. (1997) Effective health and safety management: Does firm size have an impact on health and safety practices, Unpublished report for the Department of Labour, NZIER: Wellington.

Appendix 1.

Work-age profile of the New Zealand female

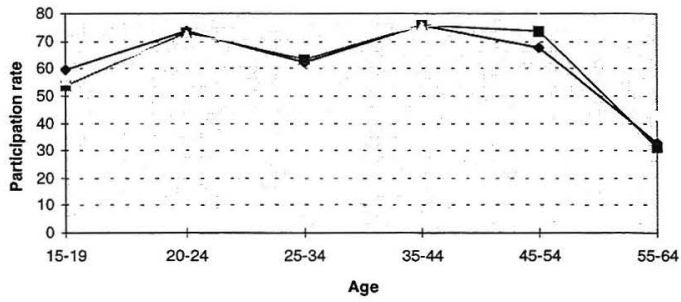

$\checkmark$ Participation rate $-1986 \rightarrow-$ Participation rate -1991

Participation rate -1996

Source: OECD; Labour force statistics, 1997 
NACEW (1993) Women and Self-employment, NACEW:

Wellington

OECD (1992) Employment Outlook: Paris

Whatman, R. (1994) Non-standard work in New Zealand - What we know, Labour Employment and Work in New Zealand: 356-366.

\section{Author}

Richard K. Bururu is an Analyst in the Labour Market Policy Group, Department of Labour, PO Box 3705,

Wellington.

E-mail: richard.bururu@1mpg.doc.govt.nz 